\title{
Foreign Direct Investment and Economic Growth in Kuwait
}

\section{Sabah Noori Al-Mihyawi*}

Institute of Administration Rusafa, Middle Technical University, Iraq

*Corresponding author: Sabah Noori Al-Mihyawi, Institute of Administration Rusafa, Middle Technical University, Iraq, Tel: +903122103035; E-mail: sa514960@gmail.com

Received Date: Apr 07, 2018; Accepted Date: Oct 11, 2018; Published Date: Oct 19, 2018

Copyright: (c) 2018 Al-Mihyawi SN. This is an open-access article distributed under the terms of the Creative Commons Attribution License, which permits unrestricted use, distribution, and reproduction in any medium, provided the original author and source are credited.

\begin{abstract}
There is a strong belief that foreign direct investment has positive effects on host countries by providing jobs, training, technology transfer, licensing agreements, creating links between foreign and domestic companies, as well as direct capital financing, thereby boosting the economic growth of any country. All this and other factors push developing countries to try to attract foreign direct investment. This result is not absolute because some studies indicate that the ability of a country to benefit from the process of attracting foreign direct investment may be affected by many internal factors, including the level of education and the availability of skilled labour, the development of financial markets. Some studies also indicate a negative impact of foreign investment flows at the level of the local economy. This paper attempts to clarify the relationship between FDI and economic growth in Kuwait for the period 2000-2016 and to determine whether the impact of investment flows negatively or positively on economic growth using a range of economic variables and using the program EViewes to perform calculations by regression analyses. The study showed that there is no relationship between foreign direct investment and economic growth, and if there is a relationship, it has a negative impact.
\end{abstract}

Keywords: FDI; GDP; Kuwait

\section{Introduction}

FDI inflows in the 1990s were concentrated on developing countries. Unlike other capital flows, foreign direct investment is less volatile and does not exhibit pro-cyclical behaviour. Thus becoming the "preferred capital flows" of developing countries. FDI inflows around the world rose from about $\$ 55$ billion in 1985 to $\$ 1.511$ billion in 2000 before falling to $\$ 573$ billion in 2003. As a share of GDP, this share increased from about 0.5 to 1.0 per cent In the 1980s to more than 5 per cent in 2000. Then fell to 1.4 per cent in 2003 [1]. Foreign investment flows around the world rose to $\$ 967$ billion in 2005 and continued to rise to $\$ 1244$ billion US dollar in 2010 [2]. In 2016, foreign investments flowing around the world reached $\$ 1746$ billion, down 1.6 percent from 2015. Although these flows declined around the world in 2016, they rose to Arab countries by 25 percent from $\$ 24.6$ billion in 2005 to $\$ 30.8$ billion in 2016 [3].

From Figure 1 the inflow of foreign direct investment (FDI) in the GCC countries has witnessed a positive development from 2000 to 2008. A larger share of FDI has often attracted three major economies in the GCC countries - Saudi Arabia, the United Arab Emirates, and Kuwait.

Kuwait's investment flows in the coming years declined to $\$ 2.873$ billion in 2012 and to $\$ 1.434$ billion in 2013, equivalent to 29 and 14 percent of total investment flows during the period 2010-2016. In 2015, direct foreign direct investment flows to the State of Kuwait amounted to about $\$ 285$ million, rising in 2016 to about $\$ 292$ million, representing about 3 percent of the total investments flowing during the research period (Figure 1).

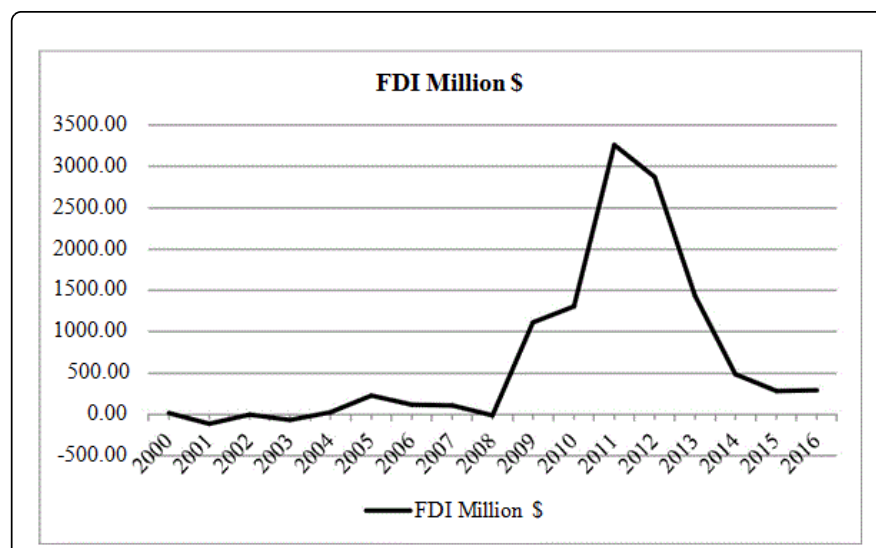

Figure 1: Foreign direct investment flows in Kuwait for the period 2000-2016 [4].

Figure 2 shows the decline in the volume of direct investment flows as a share of GDP. The figure shows that the highest percentage achieved in 2011 is equivalent to 2.11 percent of GDP. The ratio fell to 0.26 percent in 2016 .

With regard to the GDP in Kuwait for the period 2000-2016, Figure 3 shows that the trend of the value of GDP at constant prices for 2010 is an upward trend in general, where GDP rose from 115.4 billion dollars in 2010 to 142.8 billion dollars in 2016 at constant prices for 2010. However, this increase in the value of GDP at constant prices did not reflect the per capita GDP at the same prices as the per capita share declined From 38.5 thousand dollars in 2010 to 35.2 thousand dollars in 2016 at constant prices for 2010. This is because the increase in the population was not accompanied by a similar increase in the growth rate of GDP at constant prices for 2010. 
Page 2 of 4

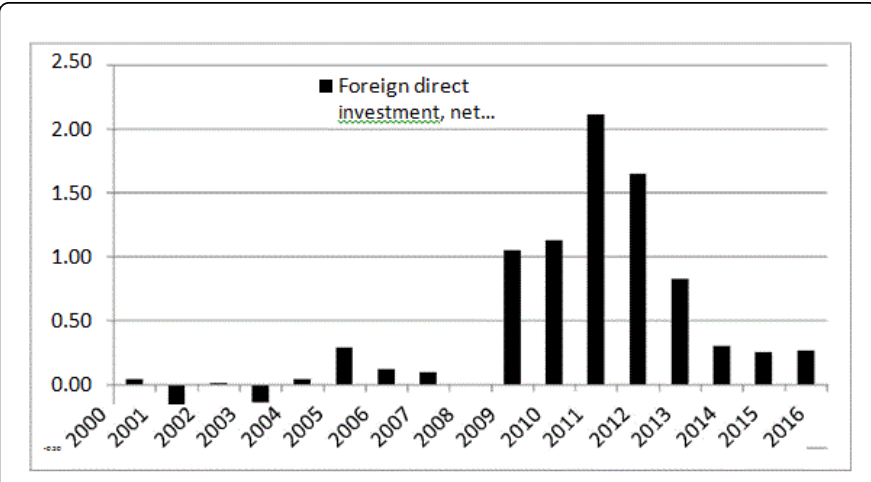

Figure 2: Foreign direct investment inflows as a percentage of GDP in Kuwait for the period 2010-2016 [4].

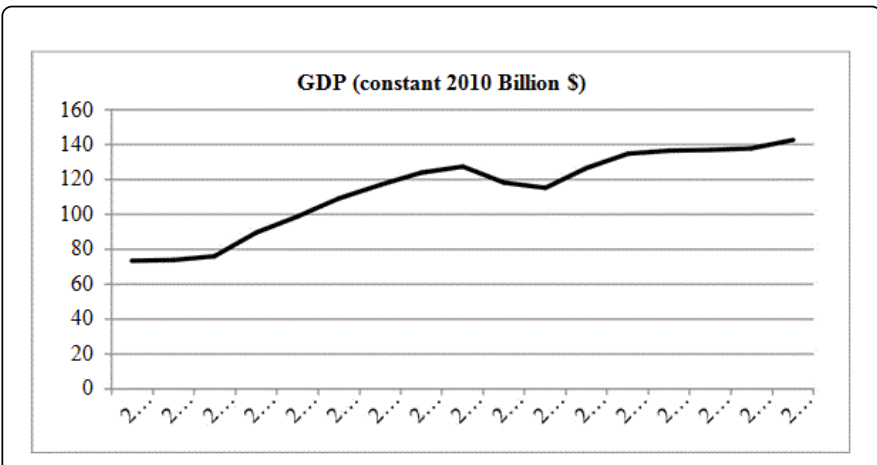

Figure 3: Gross Domestic Production in Kuwait for the period 2010-2016 (Constant 2010) [4].

\section{Objectives of the Study}

The study aims at identifying the trends of both GDP and foreign direct investment flows of the State of Kuwait for the period 2000-2016. In addition to evidence in the event of an impact of foreign direct investment on gross domestic product during the study period.

\section{Literature Review}

FDI is an important source of funds for local investment and encourages capital formation in the host country. At present, there is more attention to FDI issues at the national and international levels [2]. FDI is an influential factor in economic growth according to some views [5]. The FDI has contributed to increasing the level of education and technological progress as well as the development of infrastructure in some countries that host investment [6].

A survey by showed that out of 14 studies on the relationship between foreign investment and economic growth, 11 showed a strong positive relationship between them [7].

A study of Chowdhury shows that foreign investment is an important source of capital and promotes economic growth in host countries [8].

A study of Alfaro proved that countries with better financial systems and financial market systems could use FDI more efficiently and achieve higher growth rates [9].
A 2005 study by Kang, Y \& Du, J for a sample of 20 OECD countries showed that there is no link between foreign investment and economic growth [10].

While others researcher see foreign investment as a determinant of strengthening domestic capital and low productivity in developing economies [11].

Study of on the impact of foreign direct investment on the economic growth of developing countries, the results of their empirical tests revealed a negative correlation between the level of foreign direct investment and growth during 1970-1980 [12].

Study of Basu and Guariglia found that there was no correlation between economic growth and foreign investment and that the results of the study were mixed [13].

In summary, most studies and research have shown a positive relationship between FDI flows and economic growth.

\section{Methodology}

Several studies have examined the relationship between FDI and GDP growth from the applied side, during which different mathematical models were used to explain the relationship between the two variables. In order to understand the fundamental relationship between foreign direct investment and GDP growth in this study, the estimation equation used is the following:

Estimation Command:

\section{LS GDP C FDI}

Estimation Equation:

$\mathrm{GDP}=\mathrm{C}(1)+\mathrm{C}(2)^{\star} \mathrm{FDI}$

Where:

\section{(C): Constant}

(GDP): Gross Domestic Production (Constant 2010 million dollar)

(FDI): Foreign Direct Investment (million dollar).

Through the use of different statistical tools and the application of statistical program EViews version 10 the regression coefficients were estimated using the method of the smallest squares. The date of had collected from different sources such as the World Bank, Arab Institute for Investment Guarantee and Export Credit for the purpose of extracting the results [3].

\section{Results}

Using different estimation methods, the best results were estimated by the following equation:

\section{Substituted Coefficients:}

\section{GDP=6198.649-0.651870*FDI}

From the results Table 1 shows that the correlation between GDP and FDI is $(-0.65)$ which is moderately positive. The change in variable scores shown in the R-squared, which is 0.76 and it, is means how much the dependent variable is due to the independent variable. 


\begin{tabular}{|c|c|c|c|c|}
\hline Variable & Coefficient & Std. Error & t-Statistic & Prob. \\
\hline c & 6198.649 & 5725.643 & 1.082612 & 0.2987 \\
\hline FDI & -0.651870 & 0.698107 & -0.933768 & 0.3674 \\
\hline R-squared & 0.760022 & - & - & - \\
\hline Adjusted R-squared & 0.723102 & - & - & - \\
\hline S.E. of regression & 2812.281 & - & - & - \\
\hline Sum squared resid & $1.03 E+08$ & - & - & - \\
\hline Log likelihood & -148.1099 & - & - & - \\
\hline F-statistic & 20.58582 & - & - & - \\
\hline Prob(F-statistic) & 0.000094 & - & - & - \\
\hline Mean dependent var & 40972.64 & - & - & - \\
\hline S.D. dependent var & 5344.401 & - & - & - \\
\hline Akaike info criterion & 18.88874 & - & - & - \\
\hline Schwarz criterion & 19.03360 & - & - & - \\
\hline Hannan-Quinn criter. & 18.89616 & - & - & - \\
\hline $\begin{array}{l}\text { Dependent variable: GDP } \\
\text { Method: Least squares } \\
\text { Sample (adjusted): } 20012016 \\
\text { Included observations: } 17 .\end{array}$ & & & & \\
\hline
\end{tabular}

Table 1: Model summary.

The coefficient shows that the constant value 6198.6 and FDI value is -0.65 both with Prob values which is $<0.05$ gives insignificance. This is can also see when the AC is close to zero it is meaning there is no serial correlation. We can accept the model without serial correlation because the Prob (F-statistic) 0.000094 is less than one and it is mean that function generally is ready to analysis see (Table 2).

\begin{tabular}{|l|l|l|l|l|}
\hline S. No. & Auto Correlation (AC) & Partial Correlation (PAC) & Q-Stat & Prob. \\
\hline 1 & 0.514 & 0.514 & 5.0635 & 0.024 \\
\hline 2 & -0.082 & -0.469 & 5.2005 & 0.074 \\
\hline 3 & -0.227 & 0.132 & 6.3383 & 0.096 \\
\hline 4 & -0.182 & -0.197 & 7.1344 & 0.129 \\
\hline 5 & -0.110 & 0.027 & 7.4510 & 0.189 \\
\hline 6 & -0.080 & -0.135 & 7.6344 & 0.266 \\
\hline 7 & 0.055 & 0.222 & 7.7305 & 0.357 \\
\hline 8 & 0.156 & -0.097 & 8.6070 & 0.377 \\
\hline 9 & -0.075 & -0.274 & 8.8406 & 0.452 \\
\hline 10 & -0.277 & 0.003 & 12.520 & 0.252 \\
\hline $\begin{array}{l}\text { Sample: } 2010-2016 \\
\text { Included observations: } 17\end{array}$ & & & & \\
\hline
\end{tabular}

Table 2: Autocorrelation and correlation analysis. 
From above we can conclusion there is no serial correlation between GDP, FDI because the AC and PAC at all lags are close to zero, and all Q-statistic are insignificant.

\section{Conclusion}

The paper has examined if there is a relationship between GDP and FDI in Kuwait using time series data. Many studies deal with the relationship between FDI and GDP, some of them found a positive relationship and others found a negative relationship, while some of them found there is no relationship between them. The results of this paper show that there is no serious relationship between the GDP and FDI, and it is a negative and insignificant relationship between the GDP and FDI in Kuwait in the period 2000-2016. All these years the FDI inflows reached about 11.37 billion dollar, which is about 7.72 percent from GDP. Moreover, in the years 2001, 2003, and 2008 the FDI inflows to Kuwait were negative due to more funds investment in other countries. A new law of investment and many benefits to the investors started in 2003 in Kuwait. Therefore, the results of these benefits start shown after 2 years when the inflows of FDI started to be positive and increased generally year by year, although it has declined in some years. The government of Kuwait made another changes in the law of investment in 2013 in order to increase the FDI inflows and from the data, we cannot say that these changes gives a results.

\section{References}

1. Bank W (2005) The World Development Report.World Bank, Washington, DC, USA.
2. Mihyawi ASN (2016) Assessment of Investment Attractiveness in Arab Countries. Bus econ Invest Finance, GrinVerlag, Azienda.

3. Guarantee TA (2017) Investment Climate Report. Kuwait: The Arab Investment and Export Credit Guarantee.

4. Bank W (2018) World Bank Open Data. Retrieved from THE WORLD BANK.

5. Barro R, Xavier SIM (1995) Economic Growth. McGraw Hill, New York, 106: 407-443.

6. Busse M, Groizard J (2006) Foreign direct investment, regulations, and growth. Policy Research Working Paper Series 3882, The World Bank.

7. OECD (2002) Foreign direct investment for development: Maximising benefits, minimizing costs. OECD publishing, Paris, France.

8. Chowdhury A, Mavrotas G (2005) FDI and Growth: A Causal Relationship. Research Paper no 2005/25. Helsinki, Finland.

9. Alfaro L, Chanda A, Kalemli-Ozcan S, Sayek S (2004) FDI and economic growth: The role of local financial markets. J Int Econ, pp: 89-112.

10. Massoud N (2008) FDI and Growth in Emerging Markets: Does the Sectoral Distribution Matter-The Case of Egypt. EMG Working Paper Series, England, London, pp:1-39.

11. De Mello LR (1997) Foreign Direct Investment in Developing Countries and growth: A selective survey. J Dev Stud 36: 1-34.

12. Saltz I (1992) The Negative Correlation between Foreign DirectInvestment and Economic Growth in the Third World: Theory and Evidence. Rivista Internazionale di Scienze Economiche e Commerciali, 39: 617-633.

13. Basu P, Guariglia A (2005) "Foreign Direct Investment, Inequality and Growth. pp:1-42. 